\title{
ФОРМУВАННЯ ГЕНЕАЛОГІЧНОЇ СТРУКТУРИ ХУДОБИ УКРАЇНСЬКОЇ ЧОРНО-РЯБОЇ МОЛОЧНОЇ ПОРОДИ В СУМСЬКОМУ РЕГІОНІ ТА ДОСЛІДЖЕННЯ ӤЇ ВПЛИВУ НА ГЕНОТИП КОРІВ ЗА КАПА-КАЗЕЇНОМ
}

\author{
В. І. ЛАДИКА ${ }^{1}$, Ю. І. СКЛЯРЕНКО ${ }^{2}$, Ю. М. ПАВЛЕНКО ${ }^{1}$ \\ ${ }^{1}$ Сумський національний аграрний університет (Суми, Украйна) \\ ${ }^{2}$ Інститут сільського господарства Північного Сходу НААН (Сад, Украӥна) \\ https://orcid.org/0000-0001-6748-7616-В. І. Ладика \\ https://orcid.org/0000-0002-6579-2382 - Ю. І. Скляренко \\ https://orcid.org/0000-0002-4128-122X-Ю. М. Павленко \\ Sklyrenko9753@ukr.net
}

Вивчали особливості генезису генеалогічної структури худоби української чорно-рябої молочної породи в Сумському регіоні. Встановлено, що вона сформована двома методами: за рахунок завозу поголів'я чорно-рябих порід та подальшої його голштинізації та шляхом використання бугаїв голштинської породи на маточній основі лебединів. Результати ретроспективних досліджень вказують на те, щуо більшість завезених тварин віднесені до генеалогічних ліній Аннас Адема 30587 та М. Чіфтейна 95679. Для перетворення масиву лебединської породи використовували плідників голитинської породи ліній Айдіала 1013415, С. Т. Рокіта 252803, Соверінга 198998, М. Чіфтейна 95679, Елевейшна 1491007, С. Т. Рокіта 252803 та Астронавта 1458744. Починаючи з 2012 року більшість тварин походили від трьох голштинських ліній - Чіфа 1427381, Елевейшна 1491007 та Старбака 352790. Це сприяло подальшому збільшенню умовної кровності маточного поголів'я за голштинською породою. Згідно даних генетичних досліджень корів за генотипом капа-казеїну встановлено, щзо худобі української чорно-рябої молочної породи притаманна більша частота гомозиготних генотипів AA - 55-60\%. Частота бажаного гомозиготного генотипу ВВ складала 9-20\%. Між тваринами різного походження за батьком також існує суттєва різниця за генотипами капаказеїну.

Ключові слова: генеалогія, порода, тип, генотип, казеїн, алель, гетерозиготність

\section{PECULIARITIES OF FORMATION OF GENEALOGICAL STRUCTURE OF UKRAINIAN BLACK-AND-WHITE DAIRY BREED IN SUMY REGION AND RESEARCH OF ITS INFLUENCE ON THE GENOTYPE OF COWS BY CAPA-CASEIN}

\section{I. Ladyka', Y. I. Sklyarenko², Y. M. Pavlenko'}

${ }^{1}$ Sumy National Agrarian University (Sumy, Ukraine)

${ }^{2}$ Institute of Agriculture of Northern East of NAAS (Sad, Ukraine)

The peculiarities of the formation of the genealogical structure of the Ukrainian Black-andWhite Dairy breed in the Sumy region were studied. It is established that the formation of the genealogical structure took place due to the import of black-spotted cattle and its subsequent Holsteinization and by using bulls of Holstein breed on the uterine basis of Lebedyn breed. The results of retrospective studies indicate that most of the imported animals are attributed to the genealogical lines of Annas Adem 30587 and M. Chiftein 95679. Rokit 252803, Sovering 198998 M. Chiftein 95679, Elevation 1491007, S. T. Rokit 252803 and Astronaut 1458744. Subsequently, the use of purebred bulls of the Holstein breed increased, as a result most of the animals came from the three Holstein lines - Chif 1427381, Elevation 1491007 and Starbuck 352790. This contributed to the increase of conditional blood by Holstein breed. According to the genetic studies of cows on the 
genotype of kappa-casein, it was found that cattle of the Ukrainian Black-and-White Dairy breed are characterized by a higher frequency of homozygous AA genotypes 55-60\%. The frequency of the desired homozygous genotype of explosives was 9-20\%. There is also a significant difference in the genotypes of kappa-casein between animals of different paternal origins.

Keywords: genealogy, breed, type, genotype, casein, allele, heterozygosity

\section{ФОРМИРОВАНИЕ ГЕНЕАЛОГИЧЕСКОЙ СТРУКТУРЫ СКОТА УКРАИНСКОЙ ЧЕРНО-ПЕСТРОЙ МОЛОЧНОЙ ПОРОДЫ В СУМСКОМ РЕГИОНЕ И ИССЛЕДОВАНИЕ ЕЕ ВЛИЯНИЯ НА ГЕНОТИП КОРОВ ПО КАПА-КАЗЕИНУ}

В. И. Ладика ${ }^{1}$, Ю. И. Скляренко ${ }^{2}$, Ю. Н. Павленко ${ }^{1}$

${ }^{1}$ Сумской национальный аграрный университет (Сумы, Украина)

${ }^{2}$ Институт сельского хозяйства Северного Востока НААН (Сад, Украина)

Изучали особенности формирования генеалогической структуры украинской черно-рябой молочной породы в Сумском регионе. Установлено, что формирование генеалогической структуры происходило за счет завоза поголовья черно-пестрого скота и дальнейшей его голштинизации и путем использования быков голштинской породы на маточной основе лебединской породы. Результаты ретроспективных исследований указывают на то, что большинство ввезенных жсиотных отнесены к генеалогическим линиям Аннас Адема 30587 и М. Чифтейна 95679. Для преобразования массива лебединской породы использовали производителей голштинской породыл линий Айдиала 1013415, С. Т. Рокита 252803, Соверинга 198998 М. Чифтейн 95679, Елевейшна 1491007, С. Т. Рокита 252803 и Астронавта 1458744. В дальнейшем использование чистопородных быков голитинской породы увеличивалось, как результат - большинство животных происходили от трех голштинской линий: Чифа 1427381, Елевейшна 1491007 и Старбака 352790. Это способствовало увеличению условной кровности по голитинской породе. Согласно данным генетических исследований коров по генотипу каппа-казеина установлено, что скоту украинской черно-пестрой молочной породы характерна большая частота гомозиготных генотипов AA-55-60\%. Частота желаемого гомозиготного генотипа ВВ составляла 9-20\%. Между животныли разного происхождения по отиу также отмечена существенная разница по генотипами каппа-казеина. Ключевые слова: генеалогия, порода, тип, генотип, казеин, аллель, гетерозиготность

До складу української чорно-рябої молочної породи входять п’ять внутрішньопородних типів, кожен з яких має свої особливості. Сумський внутрішньопородний тип цієї породи створювався на маточній основі лебединської породи з використанням декількох порід чорно-рябого кореня, зокрема голштинської північноамериканської та європейської селекції і голландської порід. Крім того, популяція худоби Північного Сходу України формувалась шляхом завозу поголів'я чорно-рябих порід, в основному телиць з різних областей України та колишніх республік СРСР, а також імпорту. Ці особливості формування масиву української чорно-рябої молочної породи обумовили його неоднорідність за умовною кровністю, продуктивними якостями, екстер'єром і конституцією. Створення сумського внутрішньопородного тип української чорно-рябої молочної породи було розпочато у 1986 році. Період від початку використання на поголів ї бурої худоби бугаїв голштинської породи до апробації нового типу склав понад 20 років. Затвердили тип у 2009 році. Схема створення типу передбачала використання в базових господарствах (АФ “Косівщинська", радгосп «Степанівський», Дослідне господарство Сумської сільськогосподарської станції НААН, радгосп “Сумський”, АФ “Перше травня”) сперми бугаїв голштинської породи чорно-рябої масті. Програмою було передбачено отримання поголів'я 3 кровністю $3 / 4$ або $5 / 8$ кровності за голштинською породою та подальше розведення помісей у собі. Генеалогічна структура бугаїв які використовувалися для цієї роботи була представлена чотирма генеалогічними лініями: М. Чіфтейна 95679, С. Т. Рокіта 0252803, Р. Соверінга 198998, В. Б. Айдіала 1013415. Відповідно до розробленої програми плідники ко- 
жної з ліній застосовувались у господарствах згідно плану ротації ліній та схеми індивідуального підбору за маточним поголів'ям [4, 7, 8].

У 2012 році маточне поголів'я худоби нового типу в племінних господарствах з його розведення походило від бугаїв більше 10 генеалогічних ліній. При цьому найпоширенішими були три лінії - Старбака 352790, Чіфа 1427381 та Елевейшна 1491007.

За останні роки масив тварин сумського внутрішньопородного типу поступово скорочувався. Це було пов'язано як із зменшенням поголів'я в господарствах, так і ліквідацією підприємств взагалі. На початок 2021 року серед базових господарств 3 розведення худоби сумського внутрішньопородного типу української чорно-рябої молочної породи залишилися племзавод ДП ДГ Інституту сільського господарства Північного Сходу НААН та племрепродуктор СВК АФ «Перше травня» Сумського району.

Однією з найбільшим проблем щодо збереження цього селекційного надбання є відсутність в сумському селекційному центрі сперми плідників української чорно-рябої молочної породи сумського типу. Це робить неможливим його генетичну підтримку і прогрес. Дослідники констатують, що сперму плідників, які використовуються в регіоні, завозять 3 інших країн, що призводить до повного поглинання голштинською породою [3, 4, 6-8].

Тому безконтрольне використання покращуючих порід, яке відбувається на 85-90\% поголів'я української худоби, призводить до автоматичного зникнення генеалогічної структури українських молочних порід. Подібна ситуація характерна як товарним, так і племінним господарствам. У результаті в роботі з масивами худоби відбуваються поглинальні явища, а не заплановане відтворне схрещування [2, 3, 9].

Завдяки проведеній селекційній роботі зі створення внутріпородного типу вдалося підвищити рівень молочної продуктивності тварин, який на сьогодні складає більше 6,0 тис. кг молока. Саме рівень надоїв є головним в системі селекції молочної худоби. Також велике значення для економіки виробництва молока мають якісні показники молочної сировини. Особливо важливим це питання стало останнім часом, що пов'язано з негативними наслідками використання голштинської породи, а саме зниженням рівня жиру та білка в молоці в порівнянні 3 місцевими породами. Дослідники надають великого значення вивченню окремих фракцій білка молока та їхньому впливу на технологічні якості при його переробці. Тому в практиці широко почали застосовувати нові досягнення генетики і біотехнології. Ще ширше в світовому молочному скотарстві використовують генетичні маркери. Останні дозволяють визначити окремі генотипи у багатьох локусах і забезпечити отримання інформації про параметри популяції, такі як алель та генетичні частоти. В програмах розведення молочної худоби багатьох країн світу враховують генетичні дослідження. Це пояснюється можливістю швидкого покращення якісних та технологічних властивостей молока $[1,5,19,12,22,23]$.

Залучення сучасних молекулярно-генетичних методів діагностики в тваринництві для поліпшення технологічних властивостей молока, на думку науковців, пов'язано з вимогами переробних підприємств молочної промисловості щодо закупівлі якісної молочної сировини $[10,20]$.

Вплив генотипів капа-казеїну на якість молока досліджувалася багатьма вченими. Поліморфізм гену капа-казеїну відомий з 1964 року. До 1988 року був виділений ген капа-казеїну великої рогатої худоби і охарактеризована його структура. На сьогоднішній день описані тринадцять генетичних варіантів капа-казеїну великої рогатої худоби: А, B, C, D, E, F, H, J, I, X, $\mathrm{Az}, \mathrm{A} 1$. Найбільш часто зустрічаються генетичні варіанти A i B, інші алелі $є$ досить рідкісними $[13,21]$.

Зацікавленість цією фракцією казеїну обумовлена тим, що сир з молока корів з генотипом ВВ за капа-казеїном згущується на 25\% швидше і має згусток у два рази щільніше порівняно з молоком від корів з генотипом АА, i, відповідно, вихід сиру з молока корів генотипу ВВ на 10\% вище, ніж із молока корів генотипу АА $[12,15,18,20,24-26]$.

Але у тварин різних порід частота генотипів за капа-казеїном суттєво різниться [14]. У тварин голштинської породи найбільш часто зустрічались варіанти алелю А, а джерсейська 
порода відрізняється від них високою частотою зустрічі В-варіанту [19]. Дослідження, проведені на польській молочній худобі, вказують на те, що частка гомозигот АА у піддослідних тварин була в 3 рази більшою, ніж гетерозигот АВ і в 12 разів вищою, ніж у гомозигот ВВ. При цьому частота зустрічі алеля А складала 0,83, алеля В - 0,17 [25]. Генотипова структура словацької худоби за алелями капа-казеїну представлена трьома генотипами: АА (69,52\%), $\mathrm{AB}(27,62 \%)$ та ВВ (2,86\%). Частота алеля А становила 83,33\% і алеля В - 16,67\%. Статистичним аналізом підтверджено, що тварини з генотипом АА мали менше середнє значення вмісту білка в молоці (на 0,09\% у середньому) порівняно з худобою генотипу ВВ [22]. Науковці [17] зазначають, що тварини з генотипом ВВ серед аналізованого поголів'я худоби не зустрічалися. Частоти зустрічі генотипів АA і АВ становили 0,58 і 0,42 відповідно. Тварини із генотипом $\mathrm{AB}$ мали значно більшу молочну продуктивність порівняно 3 тваринами генотипу $\mathrm{AA}(\mathrm{P}<0,05)$. Встановлено, що корови генотипів $\mathrm{AB}, \mathrm{AA}$ та ВВ за капа-казеїном відрізнялися вмістом жиру в молоці (3,38, 3,25 та 3,14\% відповідно). При цьому капа-казеїнові варіанти не впливали на загальний білок молока [16]. Дослідники зазначають, що серед досліджуваних корів голштинської породи тварини з генотипом АА складали більшість - 57,0\%, гетерозиготні тварини $\mathrm{AB}-34,5 \%$. Інші генотипи зустрічалися рідше - AЕ 5,8\%; ВB - 0,9\%; ВE - 1,8\% [23].

Тому науковці роблять висновок, що відносний розподіл алелів та генотипів капа-казеїну у різних популяціях голштинської худоби різниться залежно від країни. Так, частота бажаного алелю В була найбільшою в сербській популяції - 49\%, іракській - 41\%. Найменшою частотою відрізнялися китайська популяція - $14 \%$, словацька - 16,7\%, російська та польська - 17\%. Бажаний генотип ВВ частіше зустрічався у сербській популяції голштинської породи - 23\%. Найменшою частотою даного генотипу характеризувалися російська $(2,9 \%)$, іранська $(2,9 \%)$, словацька $(2,8 \%)$ та канадська $(2,7 \%)$ популяції. Гомозиготні генотипи АА частіше зустрічалися у єгипетській та китайській популяціях - відповідно 85 та 74\%. Гетерозиготи були напоширинішими в іранській (82\%) та індозенійській популяціях (65\%) При цьому виявлено статистично значущу різницю між вплив генотипів капа-казеїну на середній вміст білка в молоці. Статистичний аналіз підтвердив, що генотип АА значно знижує середнє значення вмісту білка в молоці (0,09\% у середньому) порівняно з генотипом ВВ [11, 22].

Тому метою нашої роботи було дослідити особливості формування генеалогічної структури української чорно-рябої молочної породи в Сумському регіоні та вплив ії на частоту генотипів за капа-казеїном.

Матеріали та методи досліджень. Дослідження були проведені в Державному підприємстві «Дослідне господарство Інституту сільського господарства Північного Сходу НААН» Сумського району Сумської області на поголів'ї корів української чорно-рябої молочної породи $(\mathrm{n}=23$, перша група) та сумського внутрішньопородного типу української чорно-рябої молочної породи ( $\mathrm{n}=40$, друга група).

Ретроспективні дослідження проведені шляхом вивчення бази СУМС ОРСЕК за період з 1976 до 2020 року. Визначення поліморфізму гену капа-казеїну проводили в генетичній лабораторії Інституту фізіології ім. Богомольця НАН за допомогою молекулярно-біологічного аналізу розпізнавання алелів методом полімеразно ланцюгової реакції (ПЛР) у реальному часі.

Отримані результати обробляли методом варіаційної статистики за допомогою пакету програм Statistica 6,0.

Результати досліджень. На початку 60-х років минулого століття перед фахівцями Дослідного господарства колишньої Дослідної станції (нині Інститут сільського господарства Північного Сходу НААН) було поставлене завдання створення племінного високопродуктивного стада. Початком цієї роботи стало формування стада лебединської породи. Проте вже в середині 70-х років в господарство було завезено 65 теличок з господарств Московської області. За результатами ретроспективних досліджень встановлено, що генеалогічна структура поголів'я, яке було завезене до господарства, відносилось до шести ліній голштинської породи, серед яких найбільш чисельними були лінії Аннас Адема 30587 та М. Чіфтейна 95679. 
Формування масиву сумського внутрішньопородного типу української чорно-рябої молочної породи в господарстві було розпочато у середині 80 -х років минулого століття. Так на маточному поголів'ї лебединської породи почали використовувати сперму бугаїв-плідників голштинської породи. У цей процес були залучені бугаї-плідники голштинських ліній Айдіала 1013415, С. Т. Рокіта 252803, Соверінга 198998 М. Чіфтейна 95679, Елевейшна 1491007, С. Т. Рокіта 252803 та Астронавта 1458744.

Подальше формування генеалогічної структури стада української чорно-рябої молочної породи та сумського внутрішньопородного типу мали свої особливості. Так у період з 1991 до 2000 року маточне поголів'я тварин української чорно-рябої молочної породи походило від бугаїв 8 ліній, тоді як сумського внурішньопородного типу належали до 13 ліній. Найбільш поширеними лініями у перших тварин були - Айдіала 1013415, Соверінга 1989986, М. Чіфтейна 95679 у других - Елевейшна 1491007, М. Чіфтейна 95679, Чіфа 1727381 (рис. 1).

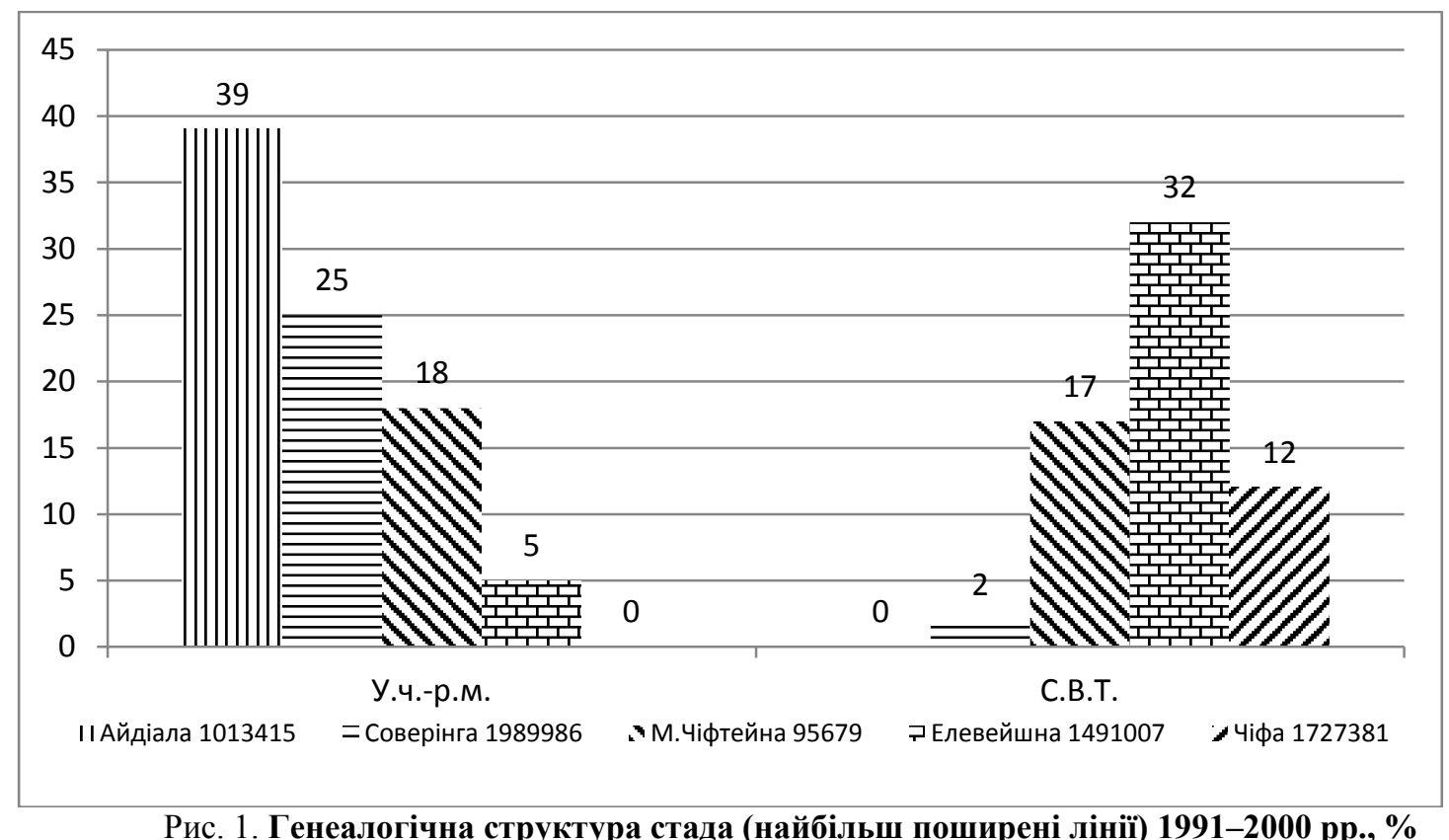

(У. ч.-р. м. - українська чорно-ряба молочна порода, С. в. п. т. - сумський внутрішньопородній тип)

Період з 2001 року характеризувався тим, що формування генеалогічної структури чорно-рябих стад у Сумському регіоні супроводжувалося використанням чистопородних бугаїв голштинської породи. Частка бугаїв української чорно-рябої молочної породи складала менше 10\% Це сприяло тому, що маточне поголів'я племінних стад належали головним чином до трьох голштинських ліній: Чіфа 1427381, Елевейшна 1491007 та Старбака 352790 (рис. 2).

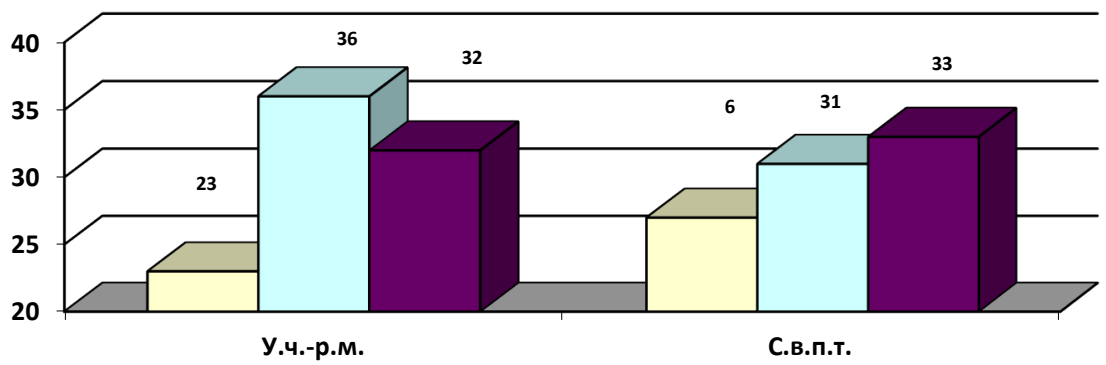

口Елевейшна 1491007 口Чіфа 1727381 口Старбака 352790

Рис. 2. Генеалогічна структура стада (найбільш поширені лінії) 2011-2020 рp., \%

(У. ч.-р. м. - українська чорно-ряба молочна порода, С. в. п. т. - сумський внутрішньопородній тип)

Також незначна кількість тварин належала до ліній Белла 1667366 та Валіанта 1650414. На початок 2021 року в господарстві більше $60 \%$ первісток української чорно-рябої молочної 
породи різного походження характеризувалися високою часткою умовної кровності за голштинською породою (рис. 3).

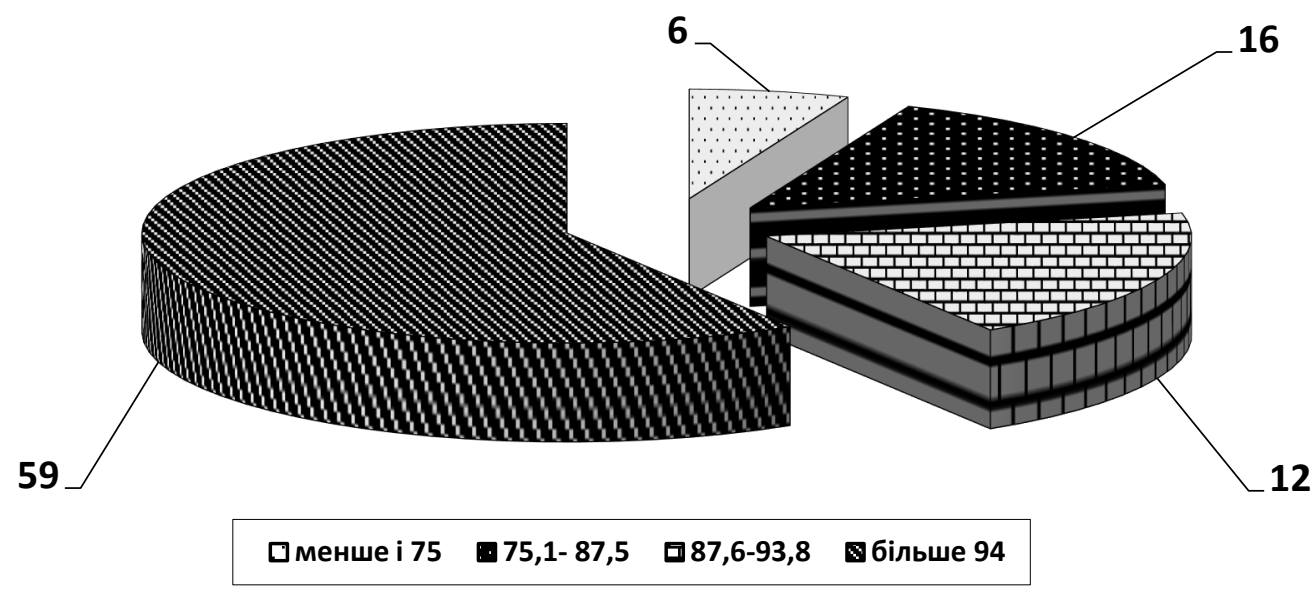

Рис. 3. Структура корів-первісток за умовна кровністю за голштинською породою (2020-2021 рp.)

Тому ми можемо стверджувати, що саме голштинські бугаї мали істотний вплив на формування генотипу, а, відповідно, і продуктивних ознак корів. Дослідники [11, 22, 23] стверджують, що коровам голштинської породи характерна низька частота бажаного генотипу ВВ за капа-казеном. Наші результати повністю співпадають $з$ даними інших науковців (рис. 4).

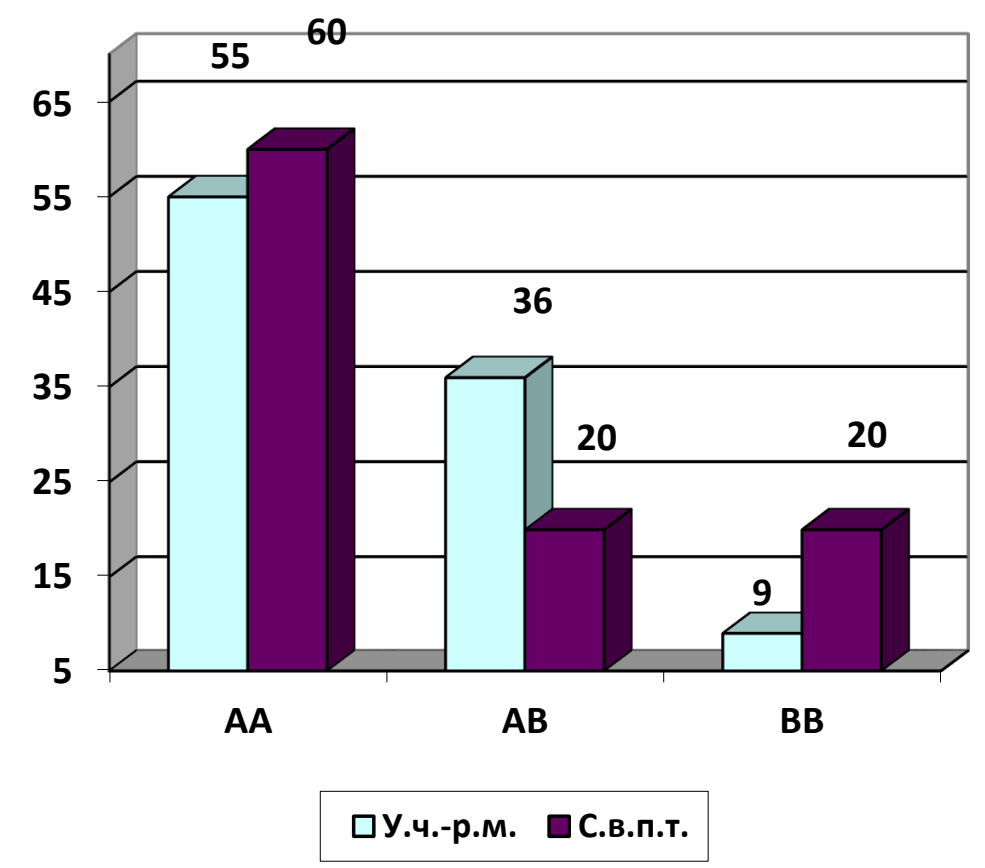

Рис. 4. Частота генотипів корів різного походження за геном капа-казеїну, \% (У. ч.-р. м. - українська чорно-ряба молочна порода, С. в. п. т. - сумський внутрішньопородній тип)

Нами встановлено, що частота за капа-казеїном дещо відрізняється у тварин різного походження. Так більшою частотою, як бажаного гомозиготного генотипу ВВ (20\%), так і гомозиготного генотипу АА (60\%) характеризувалися тварини сумського типу. Більша частота гетерозиготного генотипу АВ (36\%) була притаманна тваринам української чорно-рябої молочної породи. При цьому частота алелів була майже однаковою. Фактична гетерозиготність була дещо нижчою від очікуваної, особливо у тварин сумського внутрішньопородного типу (табл. 1). 
1. Уастота алелів та генотипів за локусом гена капа-казеӥну

\begin{tabular}{|c|c|c|c|c|c|c|c|}
\hline \multirow{2}{*}{ Порода, тип } & \multirow{2}{*}{ Розподіл ${ }^{*}$} & \multicolumn{3}{|c|}{ Генотипи, \% } & \multicolumn{2}{|c|}{ Алель, од } & \multirow{2}{*}{$\chi^{2}$} \\
\hline & & $\mathrm{AA}$ & $\mathrm{AB}$ & BB & A & $\mathrm{B}$ & \\
\hline \multirow{2}{*}{ Українська чорно-ряба молочна $(\mathrm{n}=23)$} & $\Phi$ & 55 & 36 & 9 & \multirow{2}{*}{0,73} & \multirow{2}{*}{0,27} & \multirow{2}{*}{0,076} \\
\hline & $\mathrm{O}$ & 53 & 40 & 7 & & & \\
\hline \multirow{2}{*}{$\begin{array}{l}\text { Сумський внутрішньопородний тип } \\
(\mathrm{n}=40)\end{array}$} & $\Phi$ & 60 & 20 & 20 & \multirow{2}{*}{0,70} & \multirow{2}{*}{0,30} & \multirow{2}{*}{4,116} \\
\hline & $\mathrm{O}$ & 49 & 42 & 9 & & & \\
\hline
\end{tabular}

* $\Phi$ - фактичний розподіл генотипів, $O$-очікуваний розподіл генотипів

Нами також вивчалася частота генотипів за капа-казеїном у дочок різних бугаїв, які вперше телилися у 2020-2021 роках. Між первістками різної батьківської належності встановлена різниця за частотою генотипів та алелів за капа-казеїном. Більшою частотою гомозиготного бажаного генотипу ВВ характеризувалися дочки бугаїв Альтодегрі 64633889. Високі частоти гетерозиготних генотипів АВ мали дочки бугая Моріан 1402173979. Всі дочки бугаїв Детектив 349159846, Майголд 534651702 були гомозиготами АА. Найбільша частота алелю ВВ була характерна дочкам бугая Альтадегрі 64633889 (табл. 2).

2. Частота алелів та генотипів за локусом гена капа-казеӥну у первісток різного походження

\begin{tabular}{|l|c|c|c|c|c|c|}
\hline \multirow{2}{*}{ Кличка та № батька } & \multirow{2}{*}{ Лінія } & \multicolumn{2}{|c|}{ Частота генотипів, \% } & \multicolumn{2}{c|}{ Частота алелів, $\%$} \\
\cline { 3 - 7 } & & $\mathrm{AA}$ & $\mathrm{AB}$ & $\mathrm{BB}$ & $\mathrm{A}$ & $\mathrm{B}$ \\
\hline Альтадегрі $64633889(\mathrm{n}=17)$ & Чіфа 1727381 & 50,0 & 20,0 & 30,0 & 0,600 & 0,400 \\
\hline Детектив 349159846 $(\mathrm{n}=7)$ & Старбака 352790 & 100,0 & 0,0 & 0,0 & 1,000 & 0,000 \\
\hline Майголд 534651702 $(\mathrm{n}=6)$ & Старбака 352790 & 100,0 & 0,0 & 0,0 & 1,000 & 0,000 \\
\hline Масіро 354071654 (n=14) & Елевейшна 1491007 & 42,8 & 42,8 & 14,4 & 0,640 & 0,360 \\
\hline Моріан 1402173979 $(\mathrm{n}=9)$ & Елевейшна 1491007 & 33,3 & 66,7 & 0,0 & 0,660 & 0,340 \\
\hline
\end{tabular}

Висновки. За результатами дослідження встановлені особливості формування генеалогічної структури стада української чорно-рябої молочної породи, яке формувалося за різними програмами. Генеалогічна структура на початку формування стада мала свої особливості і залежала від селекційних напрямків. Період останніх двадцяти років в регіоні характеризується тотальним використанням бугаїв голштинської породи на маточному поголів'ї української чорно-рябої молочної породи, що пояснює лінійну належність більшості худоби до ліній Чіфа 1427381, Елевейшна 1491007 та Старбака 352790. Наслідком цього є висока умовна кровність за голштинською породою у первісток. За результатами генетичних досліджень встановлено, що у стаді української чорно-рябої молочної породи генотип худоби за капа-казеїном суттєво залежав від походження. Так, тваринами сумського типу характерна більша частота гомозиготних генотипів - 80\%, при цьому частота алелів у тварин різного походження майже однакова. Походження за батьком також мало суттєвий вплив на генотип тварин за даною ознакою.

\section{БІБЛІОГРАФІЯ}

1. Базишина I. В. Формування господарськи корисних ознак молочної худоби залежно від походження за батьком. Розведення і генетика тварин. Київ, 2017. Вип. 53. С. 69-78.

2. Бойко Ю. М. Оцінка ефективності формування генеалогічної структури української бурої молочної породи : автореф. дис. ... канд. с.-г. наук : 06.02.01. Чубинське, 2012. 21 с.

3. Гетоков О. О., Долгиев М. М., Ужахов М. И. Использование быков голштинской породы для совершенствования коров красной степной породы. Зоотехния. 2014. №. 3. С. 2-4.

4. Ефименко М. Я. Формирование внутрипородной структуры создаваемых пород молочного скота. Технологія виробництва і переробки продукиії тваринництва. Біла Церква, 2010. Вип. 3 (72). С. 119-122. 
5. Костюнина О. В. Молекулярная диагнстика генетического полиморфизма основных молочных белков и их связь с технологическими свойствами молока : автореф. дис. ... канд. биол. наук : 03.00.23. Дубровицы, 2005. 23 с.

6. Кругляк Т. О. Селекційна оцінка та фактори формування господарськи корисних ознак української червоно-рябої молочної породи : автореф. дис. ... канд. с-г наук : 06.02.01. Чубинське, 2015. $20 \mathrm{c.}$

7. Ладика В. І., Котенджи Г. П., Рубцов І. О., Левченко І. В., Єфіменко М. Я., Чехівській М. Й. Щодо історії створення сумського типу української чорно-рябої молочної породи. Вісник Сумського національного аграрного університету. Серія : Тваринництво. Суми, 2003. Вип. 7. С. 120-125.

8. Скляренко Ю. І., Братушка Р. В. Подальші перспективи селекції сумського внутрішньо породного типу української чорно-рябої молочної породи. Розведення $і$ генетика тварин. Київ, 2012. Вип. 46. С. 109-111.

9. Цуп В. І., Ящук Т. С., Василів А. П. Селекційна ситуація у племінних господарствах 3 розведення великої рогатої худоби Тернопільської області та шляхів іiї покращення. Розведення і генетика тварин. Київ, 2015. Вип. 50. С. 112-117.

10. Шкурко Т. П., Іванов О. І., Іванов І. А., Оцінка молочної продуктивності первісток голштинської породи за геном капа-казеїну. Вісник Дніпропетровського державного аграрноекономічного університету. Дніпропетровськ, 2017. № 3. С. 56-59.

11. Adamov N., Atanasov B., Ilievska K., Nikolovski M., Dovenska M., Petkov V., Dovenski T. Allele and genotype frequencies of the кappa-casein (CSN3) locus in macedonian holstein-friesian cattle. Macedonian Veterinary Review. 2020. Vol. 43 (1). P. 45-54.

12. Amalfitano N., Cipolat-Gotet C., Cecchinato A., Malacarne M., Summer A., Bittante G. Milk protein fractions strongly affect the patterns of coagulation, curd firming, and syneresis. J. Dairy Sci. 2018. Vol. 102. P. 2903-2917. DOI: https://doi.org/10.3168/jds.2018-15524

13. Anggraenia A., Sumantrib C., Farajallahc A., Andreasd E. Kappa-Casein Genotypic Frequencies in Holstein-Friesian Dairy Ca le in West Java Province. Media Peternakan. 2010. Vol. 33 (2). P. 61-67.

14. Azevedo A., Nascimento C., Steinberg R., Carvalho M., Peixoto M., Teodoro R., Verneque R., Guimarães S., Machado M. Genetic polymorphism of the kappa-casein gene in Brazilian cattle. Genetics and Molecular Research. 2008. Vol. 7 (3). P. 623-630.

15. Bonfatti V., Chiarot G., Carnier P., Glycosylation of k-casein: Genetic and nongenetic variation and effects on rennet coagulation properties of milk. J. Dairy Sci. 2014. Vol. 97. P. 1961-1969. DOI: https: // doi.org/10.3168/jds.2013-7418

16. Botaro B., Vinícius Y., Simões C. Effect of the kappa-casein gene polymorphism, breed and seasonality on physicochemical characteristics, composition and stability of bovine milk. Revista Brasileira de Zootecnia. 2009. Vol. 38 (12). P. 2447-2454. DOI: https://doi.org/10.1590/S151635982009001200022

17. Deb R., Singh U., Kumar S., Singh R., Sengar G., and Sharma A. Genetic polymorphism and association of kappa-casein gene with milk production traits among Frieswal (HF $\times$ Sahiwal) cross breed of Indian origin. J. of Veterinary Research, Shiraz University IJVR. 2014. Vol. 15 (4). P. 406408.

18. Gallinat J., Qanbari S., Drögemüller C., Pimentel E., Thaller G., Tetens J. DNA-based identification of novel bovine casein gene variants. J. Dairy Sci. January. 2013. Vol. 96 (1). P. 699-709. DOI: https: //doi.org/ 10.3168/jds.2012-5908

19. Gustavsson F., Buitenhuis A., Johansson M., Bertelsen H., Glantz M., Poulsen N. Effects of breed and casein genetic variants on protein profile in milk from Swedish Red, Danish Holstein, and Danish Jersey cows. J. Dairy Sci. 2013. Vol. 97. P. 3866-3877. DOI: http://dx.doi.org/ 10.3168/jds.2013-7312 
20. Gustavsson F., Glantz M., Buitenhuis A., Lindmark M., Stalhammar H., Andren A., Paulsson M. Factors influencing chymosin-induced gelation of milk from individual dairy cows: Major effects of casein micelle size and calcium. International Dairy J. 2014. Vol. 39 (1). P. 201-208.

21. Heck J. M. L., Schennink A., van Valenberg H. J. F., Bovenhuis H., Visker M. H. P. W., van Arendonk J. A. M., van Hooijdonk A. C. M. Effects of milk protein variants on the protein composition of bovine milk. J. of Dairy Sci. 2019. Vol. 92 (3). P. 1192-1202. DOI: https: // doi:10.3168/jds.2008-1208.

22. Miluchová M., Gábor M., Candrák J., Trakovická A., and Candráková K. Association of HindIII-polymorphism in kappa-casein gene with milk, fat and protein yield in holstein cattle. Acta $\begin{array}{lllll}\text { Biochimica Polonica. 2018. o. 3. } & \text { P. 403-407 65, o. }\end{array}$ https://doi.org/10.18388/abp.2017_2313.

23. Molee A., Poompramun C., Mernkrathoke P. Effect of casein genes - beta-LGB, DGAT1, $\mathrm{GH}$, and LHR - on milk production and milk composition traits in crossbred Holsteins. Genetics and Molecular Research. 2015. Vol. 14, № 1. P. 2561-2571.

24. Sitkowska B., Neja W. Wiśniewska E. Relations between kappa-casein polymorphism (CSN3) and milk performance traits in heifer cows. J. of Central European Agriculture. 2008. Vol. 9. № 4. P. 641-644.

25. Zambrano B., Cabrera E., Portilla S., Galindo R. Kappa casein genotypes and curd yield in Holstein cows. Rev. Colomb. Cienc Pecu. 2010. Vol. 23. P. 422-428.

26. Zepeda-Batista J., Saavedra-Jiménez A., Ruíz-Flores A., Núñez-Domínguez R., RamírezValverde L. Potential influence of $\kappa$-casein and $\beta$-lactoglobulin genes in genetic association studies of milk quality traits. Asian-Australasian J. of Animal Sci. 2017. Vol. 30 (12). P. 1684-1688. DOI: https: // doi. org/ 10.5713/ajas.16.0481

\section{REFERENCES}

1. Bazyshyna, I. V. 2017. Formuvannya hospodars'ky korysnykh oznak molochnoyi khudoby zalezhno vid pokhodzhennya za bat'kom - Formation of economically useful features of dairy cattle depending on the origin of the father. Rozvedennya i henetyka tvaryn-Animal breeding and genetics. 53:69-78 (in Ukrainian).

2. Boiko, Yu. M. 2012. Otsinka efektyvnosti formuvannya henealohichnoyi struktury ukrayins'koyi buroyi molochnoyi porody : avtoref. dys. ... kand. s.-h. nauk - Estimation of efficiency of formation of genealogical structure of the Ukrainian brown dairy breed : abstract of Ph. D. dissertation. Chubynske. 21 (in Ukrainian).

3. Getokov, O. O., M. M. Dolgiev, and M. I. Uzhahov. 2014. Ispolzovanie byikov golshtinskoy porodyi dlya sovershenstvovaniya korov krasnoy stepnoy porodyi - The use of Holstein bulls to improve red steppe cows. Zootehniya - Zootechnics. 3:2-4 (in Russian).

4. Efimenko, M. Ya. 2010. Formirovanie vnutriporodnoj struktury sozdavaemyh porod molochnogo skota - Formation of the intra-breed structure of the created breeds of dairy cattle. Tekhnolohiya vyrobnytstva i pererobky produktsiyi tvarynnytstva - Technology of production and processing of livestock products. Bila Tserkva. 3(72):119-122 (in Russian).

5. Kostjunina, O. V. 2005. Molekuljarnaja diagnstika geneticheskogo polimorfizma osnovnyh molochnyh belkov i ih svjaz' s tehnologicheskimi svojstvami moloka : avtoref. dis. ... kand. biol. nauk - Molecular diagnostics of genetic polymorphism of basic milk proteins and their relationship with the technological properties of milk : abstract of Ph. D. dissertation. Dubrovicy. 23 (in Russian).

6. Kruhlyak, T. O. 2015. Selektsiyna otsinka ta faktory formuvannya hospodars'ky korysnykh oznak ukrayins'koyi chervono-ryaboyi molochnoyi porody : avtoref. dys. ... kand. s.-h. nauk - Selection assessment and factors of formation of economically useful features of the Ukrainian red-and-whitedairy breed : abstract of Ph. D. dissertation. Chubynske, 20 (in Ukrainian).

7. Ladyka, V. I., H. P. Kotendzhy, I. O. Rubtsov, I. V. Levchenko, M. Ya. Yefimenko, and M. Y. Chekhivs'kiy. 2003. Shchodo istoriyi stvorennya sums'koho typu ukrayins'koyi chorno-ryaboyi molochnoyi porody - Regarding the history of the creation of the Sumy type of Ukrainian black-and- 
white dairy breed. Visnyk Sums'koho natsional'noho ahrarnoho universytetu. Seriya : Tvarynnytstvo - Bulletin of Sumy national agrarian university. Series : Livestock. Sumy. 7:120-125 (in Ukrainian).

8. Sklyarenko, Yu. I., and R. V. Bratushka. 2012. Podal'shi perspektyvy selektsiyi sums'koho vnutrishn'oporodnoho typu ukrayins'koyi chorno-ryaboyi molochnoyi porody - Further prospects of selection of Sumy intra-breed type of Ukrainian black-and-white dairy breed. Rozvedennya $i$ henetyka tvaryn - Animal breeding and genetics. Kyyiv. 46:109-111 (in Ukrainian).

9. Tsup, V. I., T. S. Yashchuk, and A. P. Vasyliv. 2015. Selektsiyna sytuatsiya u pleminnykh hospodarstvakh z rozvedennya velykoyi rohatoyi khudoby Ternopil's'koyi oblasti ta shlyakhiv yiyi pokrashchennya - Breeding situation in breeding farms in Ternopil region and ways to improve it. Rozvedennya $i$ henetyka tvaryn - Animal breeding and genetics. Kyyiv. 50:112-117 (in Ukrainian).

10. Shkurko, T. P., O. I. Ivanov, I. A. Ivanov. 2017. Otsinka molochnoyi produktyvnosti pervistok holshtyns'koyi porody za henom kapa-kazeyinu - Estimation of milk productivity of Holstein breed firstborns by kappa-casein gene. Visnyk Dnipropetrovs'koho derzhavnoho ahrarno-ekonomichnoho universytetu - Bulletin of Dnipropetrovsk state agrarian and economic university. Dnipropetrovs'k, 3:56-59 (in Ukrainian).

11. Adamov, N., B. Atanasov, K. Ilievska, M. Nikolovski, M. Dovenska, V. Petkov, and T. Dovenski. 2020. Allele and genotype frequencies of the kappa-casein (CSN3) locus in macedonian holstein-friesian cattle. Macedonian Veterinary Review. 43(1):45-54 (in English).

12. Amalfitano, N., C. Cipolat-Gotet, A. Cecchinato, M. Malacarne, A. Summer, and G. Bittante. 2018. Milk protein fractions strongly affect the patterns of coagulation, curd firming, and syneresis. J. Dairy. 102:2903-2917 (in English). DOI: https://doi.org/10.3168/jds.2018-15524

13. Anggraenia, A., C. Sumantrib, A. Farajallahc, and E. Andreasd. 2010. Kappa-Casein Genotypic Frequencies in Holstein-Friesian Dairy $\mathrm{Ca}$ le in West Java Province. Media Peternakan. 33(2):61-67 (in English).

14. Azevedo, A., C. Nascimento, R. Steinberg, M. Carvalho, M. Peixoto, R. Teodoro, R. Verneque, S. Guimarães, and M. Machado. 2008. Genetic polymorphism of the kappa-casein gene in Brazilian cattle. Genetics and Molecular Research. 7(3):623-630 (in English).

15. Bonfatti, V., G. Chiarot, and P. Carnier. 2014. Glycosylation of k-casein: Genetic and nongenetic variation and effects on rennet coagulation properties of milk. J. Dairy. 97:1961-1969 (in English). DOI: https: // doi.org/10.3168/jds.2013-7418

16. Botaro, B., Y. Vinícius, and C. Simões. 2009. Effect of the kappa-casein gene polymorphism, breed and seasonality on physicochemical characteristics, composition and stability of bovine milk. Revista Brasileira de Zootecnia. 38(12):2447-2454 (in English). DOI: https://doi.org/10.1590/S1516-35982009001200022

17. Deb, R., U. Singh, S. Kumar, R. Singh, G. Sengar, and A. Sharma. 2014. Genetic polymorphism and association of kappa-casein gene with milk production traits among Frieswal $(\mathrm{HF} \times \mathrm{Sa}-$ hiwal) cross breed of Indian origin. Journal of Veterinary Research. Shiraz University IJVR. 15(4):406-408 (in English).

18. Gallinat, J., S. Qanbari, C. Drögemüller, E. Pimentel, G. Thaller, and J. Tetens. 2013. DNAbased identification of novel bovine casein gene variants. J. Dairy Sci. 96(1):699-709 (in English). DOI: https: //doi.org/ 10.3168/jds.2012-5908

19. Gustavsson, F., A. Buitenhuis, M. Johansson, H. Bertelsen, M. Glantz, and N. Poulsen. 2013. Effects of breed and casein genetic variants on protein profile in milk from Swedish Red, Danish Holstein, and Danish Jersey cows. J. Dairy Sci.. 97:3866-3877 (in English). DOI: http://dx.doi.org/ $10.3168 /$ jds.2013-7312

20. Gustavsson, F., M. Glantz, A. Buitenhuis, M. Lindmark, H. Stalhammar, A. Andren, and M. Paulsson. 2014. Factors influencing chymosin-induced gelation of milk from individual dairy cows : Major effects of casein micelle size and calcium. International Dairy Journal. 39(1):201-208 (in English).

21. Heck, J. M. L., A. Schennink, H. J. F. van Valenberg, H. Bovenhuis, M. H. P. W. Visker, J. A. M. van Arendonk, and A. C. M. van Hooijdonk. 2019. Effects of milk protein variants on the 
protein composition of bovine milk, Journal of Dairy Science. 92(3):1192-1202 (in English). DOI: https: // doi:10.3168/jds.2008-1208

22. Miluchová, M., M. Gábor, J. Candrák, A. Trakovická, and K. Candráková. 2018. Association of HindIII-polymorphism in kappa-casein gene with milk, fat and protein yield in holstein cattle. Acta Biochimica Polonica. 65(3):403-407 (in English). DOI: https://doi.Org/10.18388/abp. 2017_2313.

23. Molee, A., C. Poompramun, and P. Mernkrathoke. 2015. Effect of casein genes - beta-LGB, DGAT1, GH, and LHR - on milk production and milk composition traits in crossbred Holsteins. Genetics and Molecular Research. 14(1):2561-2571 (in English).

24. Sitkowska, B., W. Neja, and E. Wiśniewska. 2008. Relations between kappa-casein polymorphism (CSN3) and milk performance traits in heifer cows. Journal of Central European Agriculture. 4:641-644 (in English).

25. Zambrano, B., E. Cabrera, S. Portilla, and R. Galindo. 2010. Kappa casein genotypes and curd yield in Holstein cows. Rev. Colomb. Cienc Pecu. 23:422-428 (in English).

26. Zepeda-Batista, J., A. Saavedra-Jiménez, A. Ruíz-Flores, R. Núñez-Domínguez, and L. Ramírez-Valverde. 2017. Potential influence of $\kappa$-casein and $\beta$-lactoglobulin genes in genetic association studies of milk quality traits. Asian-Australasian Journal of Animal Sciences. 30(12):16841688 (in English). DOI: https: // doi. org/ 10.5713/ajas.16.0481

Одержано редколегією 15.03 .2021 р.

Прийнято до друку 26.04.2021 p. 